\title{
Changes of antioxidant potential under the experimental periodontitis development
}

\author{
A.Ye. Demkovych, Yu.I. Bondarenko \\ SHEI “I. Horbachevsky Ternopil State Medical University”; e-mail: demkovushae@tdmu.edu.ua
}

\begin{abstract}
The results of biochemical studies of the antioxidant preventive system are given in the article. They were determined by the activity of superoxide dismutase (SOD), catalase, ceruloplasmin, glutathione peroxidase, glutathione reductase and reduced glutathione on the $7^{\text {th }}, 14^{\text {th }}$ and $30^{\text {th }}$ days of development of experimental periodontitis. It is shown that the generation of reactive oxygen species is associated with an increase in the activity of immune processes, which becomes more potent and provides a protracted character to the inflammatory process in the periodontal tissues. In that is paid attention to the characteristic dynamics of changes in the activity indices of lipid peroxidative processes and the antioxidant protective system in the development of experimental periodontitis. In the early period of development of experimental periodontitis, that is, on the $7^{\text {th }}$ day, the activity of SOD in the blood serum decreased, and later, on the $14^{\text {th }}$ and $30^{\text {th }}$ days, it increased. On the $7^{\text {th }}$ day of the experiment, an increase of the catalase activity and ceruloplasmin in the blood serum was found, respectively) in comparison with the control. On the $14^{\text {th }}$ day catalase activity and ceruloplasmin was decreased as compared to the group of animals examined on the $7^{\text {th }}$ day of the experiment. On the $30^{\text {th }}$ day their levels in the blood serum still is remained decreased. The dynamics of indices reduced glutathione were similar to the dynamics of superoxide dismutase activity, that is, on the $7^{\text {th }}$ day of the experiment there was a decrease. The partial increase enzymic activity of the glutathione system (glutathione peroxidase, glutathione reductase) occurred on the $14^{\text {th }}$ day of the inflammation but subsequently these parameters became the opposite of changes. It is established that in the conditions of formation and course of experimental periodontitis the intensity of antioxidant protection activity varies. Key words: periodontitis; catalase; superoxide dismutase; ceruloplasmin; glutathione; glutathione peroxidase; glutathione reductase; antioxidant protection.
\end{abstract}

\section{INTRODUCTION}

The improvement of the already known and creation of the new methods of the periodontitis treatment is one of the urgent problem of modern dentistry, because the frequency of periodontal diseases worldwide is within of 5-20\% and increases with age to $75 \%[1,2]$. Explaining the mechanisms of their development are considered on the level of metabolic processes, disorders are caused by the damage of the periodontal complex structures, which leads to the formation of inflammation of various degree intensity. Activation of lipid peroxidation (LPO) is one of the triggers of stress damage with disruption of cellular metabolism, which, first of all, are associated with damage to cellular and subcellular (C) A.Ye. Demkovych, Yu.I. Bondarenko membranes [3-6]. For neutralize of excess lipid peroxidation and maintain a stationary intracellular concentration of free radicals and lipoperoxide in the organism there are enzyme and non-enzyme systems of antioxidant protection $[7,8]$. The purpose of this study was to define the pathogenetic role of the enzyme and nonenzyme link of antioxidant protection system in the dynamics of the experimental periodontitis development.

\section{METHODS}

The experiments were performed with use of white clinical healthy male rats $150-200 \mathrm{~g}$ weight in conditions of vivarium, according to the sanitary standards and requirements of GLP. 
The animals were supported on standard diet, balanced by nutritional elements. The investigations was performed according to the general rules and regulations of the European Convention for the Protection of vertebrate animals that use for experimental and other scientific purposes (Strasbourg, 1986), the General ethical animal experimentation (Kyiv, 2001). The experimental animals were randomly selected and divided into 3 groups: I - intact animals $(n=10)$; II - animals with experimental periodontitis on the $7^{\text {th }}$ day of the study $(n=8)$; III - animals with experimental periodontitis on the $14^{\text {th }}$ day of the study $(n=8)$; IV - animals with experimental periodontitis on the $30^{\text {th }}$ day of the study $(n=8)$. Experimental bacterial-immune periodontitis in experimental animals was caused by injection into the tissue of the periodontal complex of the microorganisms mixture diluted with egg protein [9]. To enhance the immune response, an injection of complete Freund's adjuvant was simultaneously injected into the rats paw. In the time performance of the studies with animals of group IV, on the $14^{\text {th }}$ day, was repeated injection of pathogenic and adjuvant. On the $7^{\text {th }}$, $14^{\text {th }}$ and $30^{\text {th }}$ day experimental animals were exsanguinated under thiopental anesthesia. For further research the blood serum was selected. In serum was determined the indices of superoxide dismutase, catalase activity, content of reduced glutathione, glutathione reductase and glutathione peroxidase. The determination of superoxide dismutase activity was carried out by a technique based on the ability of the enzyme to inhibit the reduction of nitrotetrazolium blue [10]. For the study, $1 \mathrm{ml}$ of blood was taken, which was prepared on phosphate buffer $(\mathrm{pH}=$ 7.4). Preliminary treatment of the material with chloroform-alcohol mixture and $\mathrm{KH}_{2} \mathrm{PO}_{4}$ was carried out, followed by centrifugation. To the supernatant were added $1.3 \mathrm{ml}$ of pyrophosphate buffer ( $\mathrm{pH} 8.3$ ), $1 \mathrm{ml}$ of nitrotetrazolium blue solution, $0.3 \mathrm{ml}$ of phenazinmetasulfate solution and $2 \mathrm{ml}$ of $\mathrm{NADPH}_{2}$ (Nicotinamide adenine dinucleotide) solution. The samples were kept in the dark and photometrwals on a SF-46 spectro- photometer $(540 \mathrm{~nm})$ in a $1 \mathrm{~cm}$ cuvette against samples to which $\mathrm{NADPH}_{2}$ was not added. The control was a phosphate buffer. The activity of the enzyme, which is able to inhibit the reduction of nitrotetrazolium blue by $50 \%$, was taken as 1 conditioned. units. Determination of catalase activity [11] is based on the ability of hydrogen peroxide to form a stable colored complex with ammonium molybdate, the intensity of which is inversely proportional to the activity of catalase in the test substrate. Blood serum from which $10 \%$ homogenate on Tris buffer $(\mathrm{pH}=7.8)$ was prepared in the cold. The reaction was started by adding $0.1 \mathrm{ml}$ of plasma or homogenate to $2 \mathrm{ml}$ of a $0.03 \%$ hydrogen peroxide solution. After 10 minutes, the reaction was stopped by the addition of $1 \mathrm{ml}$ of $4 \%$ ammonium molybdate. The color intensity was measured on a SF-46 spectrophotometer at $410 \mathrm{~nm}$. The activity of catalase was expressed in microcatal per liter (mccat / 1).

The serum level of ceruloplasmin was determined by a method that is based on the study of the optical density of oxidation products of n-phenylenediamine in the presence of ceruloplasmin [12]. Its amount is proportional to the intensity of the color. The samples were held for 30 minutes at $4{ }^{\circ} \mathrm{C}$. and then their optical density was determined against the control on a SF-46 spectrophotometer at $530 \mathrm{~nm}$ and expressed in milligrams per liter ( $\mathrm{mg} / \mathrm{1})$.

The principle of the method for determining the concentration of reduced glutathione is [13] in the interaction of 5,5-dithiobis (2-nitrobenzoic acid) (Elman reagent) with the $\mathrm{SH}$ groups of the substrate for study. In this case, a thiontrophenyl anion is formed, the amount of which is directly proportional to the content of the $\mathrm{SH}$ groups. Up to $0.2 \mathrm{ml}$ of blood serum (1:4), $1.6 \mathrm{ml}$ of $3 \%$ $\mathrm{H}_{2} \mathrm{O}_{2}$ and $0.2 \mathrm{ml}$ of $25 \%$ sulfosalicylic acid were added. Centrifuged, then $2.5 \mathrm{ml}$ of $0.2 \mathrm{~mol} / 1$ Tris buffer $(\mathrm{pH}=8.4)$ and $0.05 \mathrm{ml}$ of a $0.04 \%$ solution of the Elman reagent were added to 0.5 $\mathrm{ml}$ of the centrifuge. Instead of the test material, $0.2 \mathrm{ml}$ of water was added to the control tube. After 10 minutes, the photometric test samples 
were run on a SF-46 spectrophotometer at $412 \mathrm{~nm}$ against the control. The concentration of the reduced glutathione was calculated from the molar extinction coefficient for the thionotrophenyl anion of $11400 \mathrm{~mol} / \mathrm{l}^{-1} \square \mathrm{cm}^{-}$ 1 , expressed in millimoles per liter $(\mathrm{mmol} / 1)$.

Glutathione reductase activity was calculated in the control and test sample, the difference between the amount of $\mathrm{NADPH}_{2}$ consumed in the enzymatic reduction of oxidized glutathione to centrifugate spectrophotometrically (SF-46, $340 \mathrm{~nm}$ ) and was expressed in $\mathrm{mmol} / \mathrm{min} \times 1$. [14]. Glutathione peroxidase activity was determined according to the method described in [14]. Enzyme activity was calculated by the difference between the amount of reduced glutathione in the control (without $\mathrm{H}_{2} \mathrm{O}_{2}$ ) and test samples, expressed in $\mathrm{mmol} / \mathrm{min} \times 1$.

The results were analyzed using the nonparametric statistical methods [15] in the Excel software (Microsoft, USA) and STATISTICA 10.0 (Statsoft, USA). The reliability of the differences in values between independent quantitative values was determined with a normal distribution according to the Mann-Whitney U criterion [16].

\section{RESULTS AND DISCUSSION}

These studies were performed in accordance with suggested and patented our pattern of experimental periodontitis [17], which reflects the role of bacterial and immune disorders in the mechanisms of inflammation development in the periodontal complex. Study of experimental periodontitis in that version and indices of bacterial-immune inflammation before were not investigated.

The introduction into the periodontal tissue of a microorganisms mixture with diluted protein caused development of hyperergic inflammatory process, typical changes in the soft tissues of the lower jaw, accompanied by edema and hyperemia of the mucosa and the characteristic of the symptoms were the same as the changes in humans [18]. Significant quantitative changes were found in prooxidant-antioxidant system [19].

The results of the biochemical study show changes in the enzymic link of the antioxidant system in particular of superoxide dismutase (SOD) and catalase activity in groups I-IV of the experimental animals (Table). It was found that antioxidant enzymes activity in different periods of formation the inflammatory process, depended on character of pathogenic factors.

At the early stage of experimental periodontitis development, that is on the $7^{\text {th }}$ day, a decrease in the activity of SOD in the blood serum (by 1.78 times; $\mathrm{P}<0.01$ ) was observed, but later, on the $14^{\text {th }}$ day, the activity of the enzyme changed in the opposite direction, that is, increased by 1.42 times $(\mathrm{P}<0.01)$ compared to the animals on the $7^{\text {th }}$ day of the experiment, but did not reach the mean values of the intact group of animals (by 1.25 times; $\mathrm{P}<0.01$ ). In comparison of the enzyme activity on the $30^{\text {th }}$ day of experimental periodontitis in relation to the experimental group on the $14^{\text {th }}$ day further but insignificant increase was observed (by 1.09 times $(\mathrm{p}<0.01)$, which exceeded by 1.56 times $(\mathrm{P}<0.01)$ activity, which was observed on the $7^{\text {th }}$ day of the experiment. However, the studied indices was lower relative to the control group of animals (by 1.14 times; $\mathrm{P}<0.01$ ). These results confirm that on the $14^{\text {th }}$ day there is a further development of alterative changes and the inclusion of additional stimulation of SOD activity in response to an increased level of oxygen radical in the center of inflammation [20, 21] (Fig. 1).

So, according to our results, on the 14 th day of experimental investigation the SOD activity exceeded the index of the $7^{\text {th }}$ day, that is related to the response of this enzyme to elevated level of the superoxide anion-radical, as well as the amplification through transcription signaling molecule (NF-kB) with induction of this enzyme synthesis [22].

The study of one from the key enzymes of antioxidant system - catalase in the blood serum in different periods of experimental periodontitis shown an opposite trend of changes as compared 
The activity of antioxidant enzymes in the rat's serum for different periods of experimental periodontitis

$(\mathbf{M} \pm \mathbf{m})$

\begin{tabular}{|c|c|c|c|c|}
\hline $\begin{array}{c}\text { The form of the } \\
\text { experiment }\end{array}$ & $\begin{array}{l}\text { Control, intact } \\
\text { animals }\end{array}$ & \multicolumn{3}{|c|}{ White rats with periodontitis } \\
\hline $\begin{array}{l}\text { Experiment duration } \\
\text { (days) }\end{array}$ & - & 7 & 14 & 30 \\
\hline Number of the animals & 10 & 8 & 8 & 8 \\
\hline $\begin{array}{l}\text { Superoxide dismutase, } \\
\text { conditioned. } \\
\text { units } / \mathrm{ml}\end{array}$ & $2.294 \pm 0.066$ & $\begin{array}{c}1.292 \pm 0.048 \\
\mathrm{P}_{1}<0.01\end{array}$ & $\begin{array}{c}1.840 \pm 0.040 \\
\mathrm{P}_{1}<0.01, \mathrm{P}_{2}<0.01\end{array}$ & $\begin{array}{c}2.013 \pm 0.012 \\
\mathrm{P}_{1}<0.01, \mathrm{P}_{2}<0.01 \\
\mathrm{P}_{3}<0.01\end{array}$ \\
\hline Catalase, mcat./1 & $0.118 \pm 0.001$ & $\begin{array}{c}0.521 \pm 0.008 \\
\mathrm{P}_{1}<0.01\end{array}$ & $\begin{array}{c}0.382 \pm 0.008 \\
\mathrm{P}_{1}<0.01, \mathrm{P}_{2}<0.01\end{array}$ & $\begin{array}{c}0.337 \pm 0.003 \\
\mathrm{P}_{1}<0.01, \mathrm{P}_{2}<0.01 \\
\mathrm{P}_{3}<0.01\end{array}$ \\
\hline $\begin{array}{l}\text { Reduced glutathione, } \\
\mathrm{mmol} / \mathrm{l}\end{array}$ & $4.120 \pm 0.002$ & $\begin{array}{c}2.293 \pm 0.003 \\
\mathrm{P}_{1}<0.01\end{array}$ & $\begin{array}{c}3.160 \pm 0.004 \\
\mathrm{P}_{1}<0.01, \mathrm{P}_{2}<0.01\end{array}$ & $\begin{array}{c}2.792 \pm 0.003 \\
\mathrm{P}_{1}<0.01, \mathrm{P}_{2}<0.01 \\
\mathrm{P}_{3}<0.01\end{array}$ \\
\hline Ceruloplasmin, mg / 1 & $1.09 \pm 0,01$ & $\begin{array}{c}3.09 \pm 0.01 \\
\mathrm{P}_{1}<0.01\end{array}$ & $\begin{array}{c}2.70 \pm 0.07 \\
\mathrm{P}_{1}<0.01, \mathrm{P}_{2}<0.01\end{array}$ & $\begin{array}{c}2.25 \pm 0.07 \\
\mathrm{P}_{1}<0.01, \mathrm{P}_{2}<0.01, \\
\mathrm{P}_{3}<0.01\end{array}$ \\
\hline $\begin{array}{l}\text { Glutathione reductase, } \\
\mathrm{mmol} / \mathrm{min} \times 1\end{array}$ & $0.490 \pm 0.005$ & $\begin{array}{c}0.173 \pm 0.003 \\
\mathrm{P}_{1}<0.01\end{array}$ & $\begin{array}{c}0.384 \pm 0.005 \\
\mathrm{P}_{1}<0.01, \mathrm{P}_{2}<0.01\end{array}$ & $\begin{array}{c}0.283 \pm 0.002 \\
\mathrm{P}_{1}<0.01, \mathrm{P}_{2}<0.01, \\
\mathrm{P}_{3}<0.01\end{array}$ \\
\hline $\begin{array}{l}\text { Glutathione peroxidase, } \\
\mathrm{mmol} / \mathrm{min} \times 1\end{array}$ & $0.594 \pm 0.003$ & $\begin{array}{c}0.381 \pm 0.005 \\
\mathrm{P}_{1}<0.01\end{array}$ & $\begin{array}{c}0.535 \pm 0.006 \\
\mathrm{P}_{1}<0.01, \mathrm{P}_{2}<0.01\end{array}$ & $\begin{array}{c}0.461 \pm 0.009 \\
\mathrm{P}_{1}<0.01, \mathrm{P}_{2}<0.01, \\
\mathrm{P}_{3}<0.01\end{array}$ \\
\hline
\end{tabular}

Notes: $1 . \mathrm{P}_{1}$ - significant of differences in relation to intact animals;

2. $\mathrm{P}_{2}-$ significant of differences in relation to animals with experimental periodontitis on the $7^{\text {th }}$ day of the study;

3. $\mathrm{P}_{3}-$ significant of differences in relation to animals with experimental periodontitis on the $14^{\text {th }}$ day of the study.

to the values of SOD activity. In addition, the degree of expression was somewhat higher. In particular, in the early stage of experimental periodontitis, which included the $7^{\text {th }}$ day of the experiment, increase in catalase activity in serum was observed as compared to the control (by 4.42 times; $\mathrm{P}<0.01$ ).

In the following stage of the inflammatory process development in the tissues of the periodontal complex (on the $14^{\text {th }}$ day), the catalase level was decreased in the blood serum (by 1.36 times; $\mathrm{P}<0.01$ ) in comparison with the group of animals on the $7^{\text {th }}$ day of the experiment, but as compared with the control group, remained at a high level in relation to this index in the control group ( by 3.24 times; $\mathrm{P}<0.01$ ). That proves a large pool of use of that enzyme and maintained reserve capacity for antioxidant protection (Fig. 2).

In the later period, on the $30^{\text {th }}$ day for the inflammatory process in the periodontal tissue, the serum level of catalase activity was decreased in relation to the indices on the $7^{\text {th }}$ (by 1.55 times; $\mathrm{P}<0.01$ ) and $14^{\text {th }}$ days (by 1.13 times; $\mathrm{P}<0.01)$. As compared this index with the parameters of the control group, its activity in the serum remained at a high level, that is, it was increased (by 2.86 times; $\mathrm{P}<0.01$ ). 


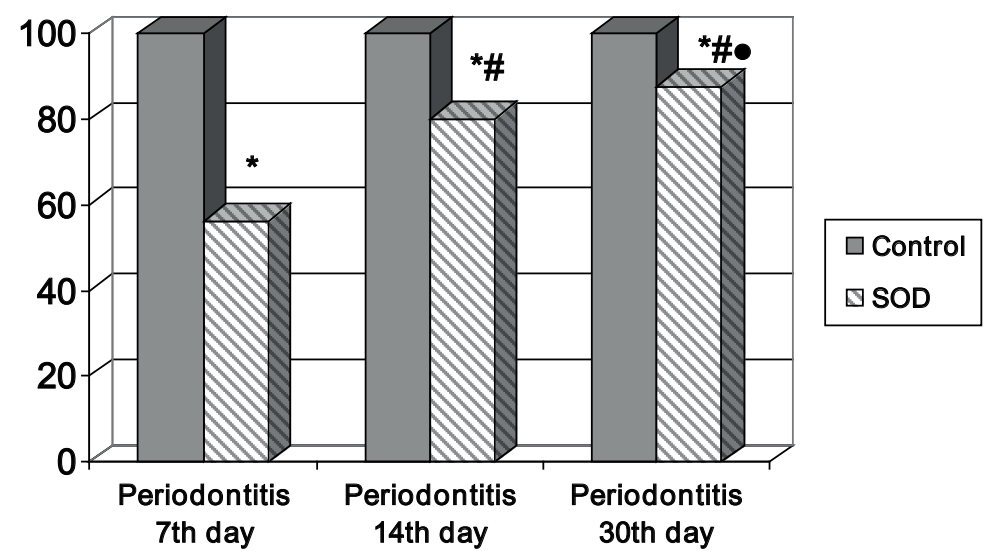

Fig. 1. Superoxide dismutase activity of rats' blood serum with the experimental periodontitis ( $\%$ of the control). Notes: * significant of differences in relation to the intact animals $(\mathrm{P}<0.01)$; \# - significant of differences in relation to the animals with periodontitis on the $7^{\text {th }}$ day of the study $(\mathrm{P}<0.01)$; $\bullet$ - significant of differences in relation to the animals with periodontitis on the $14^{\text {th }}$ day of the study $(\mathrm{P}<0.01)$

In consequence of catalase activity decrease appear possibility of developing a deficiency of the antioxidant protective system to completely neutralize the lipid peroxidation products, which excessively are formed during the development of the inflammatory process in the periodontal tissues and their entrance into the bloodstream, that ultimately leads to the development of oxidative stress as an important factor of alteration and the formation of a protracted inflammatory process with possible complications at the systemic level.
An important element of antioxidant protection is also ceruloplasmin (feroxidase) copper-containing protein, which, similarly to superoxide dismutase, carries out the dismutation reaction, but unlike SOD, which protects intracellular structures, it functions and neutralizes oxygen active species in the blood, preventing peroxidation of lipids cellular membranes $[23,24]$.

Cerulloplasmin is a ferroxidase enzyme is considered as a transport form of copper, which is synthesized in the liver and transported

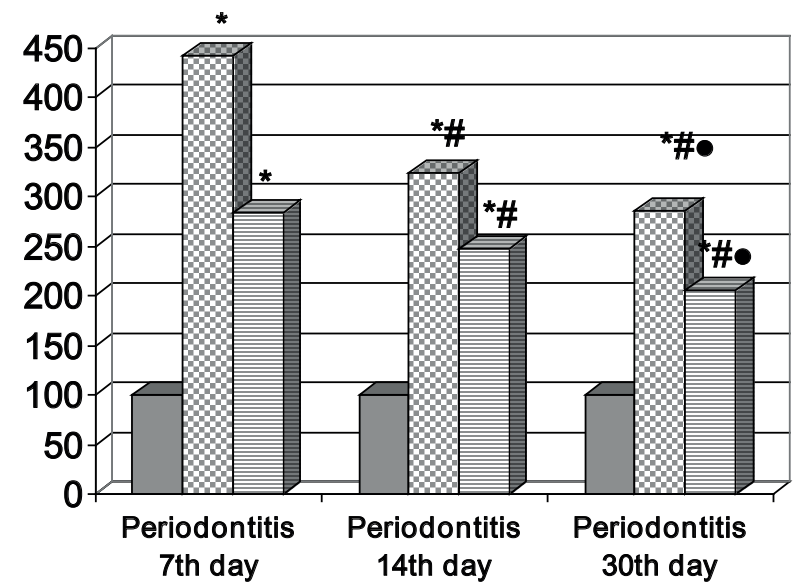

\begin{tabular}{|l|}
\hline$\square$ Control \\
$\square$ Catalase \\
$\square$ Ceruloplasmin \\
\hline
\end{tabular}

Fig. 2. Catalase activity and ceruloplasmin levels in rats 'blood serum with the experimental periodontitis ( $\%$ of the control). Notes: * - significant of differences in relation to the intact animals $(\mathrm{P}<0.01)$; \# - significant of differences in relation to the animals with periodontitis on the $7^{\text {th }}$ day of the study $(\mathrm{P}<0.01) ; \bullet$ - significant of differences in relation to the animals with periodontitis on the $14^{\text {th }}$ day of the study $(\mathrm{P}<0.01)$ 
to organs. It's mainly antioxidant with effect similar to glutatione peroxidase. In addition, ceruloplasmin is regarded to proteins of acute phase inflammation at the systemic level [25].

In animals of the second experimental group, on the $7^{\text {th }}$ day of the study, showed an increased level ceruloplasmin content in the blood serum (by 2.84 times; $\mathrm{P}<0.01$ ) in relation to the control group (Table, Fig. 2). In rats of the third experimental group, on the $14^{\text {th }}$ day, the content of ceruloplasmin was kept at a high level (exceeding by 2.48 times; $\mathrm{P}<0.01)$ in comparison with the control group. In comparison of ceruloplasmin content in the blood serum of both experimental groups, it prevailed in the animals was examined on the $7^{\text {th }}$ day of the experiment (by 1.14 times; $\mathrm{P}<0.01$ ). Through $30^{\text {th }}$ days of the experiment, the content of that antioxidant in the blood was decreased in relation on the previous periods (by 1.37 times; $\mathrm{P}<0.01$ and by 1.20 times; $\mathrm{P}<0.01$, respectively) and at the same time it was higher than in control animals (by 2.06 times; $\mathrm{P}<0.01$ ).

At the same time, it is paid attention to changes in the activity of the glutathione system - reduced glutathione and enzymes of glutathione reductase and glutathione peroxidase (Table, Fig. 3). It was found that on the $7^{\text {th }}$ day of the development of experimental periodontitis, the content of reduced glutathione in the blood was lower in relation intact animals (by 1.80 times; $\mathrm{P}<0.01)$. Later, on the $14^{\text {th }}$ day of the study, its level in the blood serum was increased (by 1.38 times; $p<0.01$ ) in comparison with the group of animals, which was termined on the $7^{\text {th }}$ day in an acute phase of the inflammatory process in the periodontal tissues, however this index still kept at a lower level as compared with the intact group (by 1.30 times; $\mathrm{P}<0.01$ ).

Later, on the $30^{\text {th }}$ day of the development of the inflammatory process, the content of reduced glutathione continued to decrease (by 1.13 times; $\mathrm{P}<0.01$ ) in relation to groups of animals with experimental periodontitis on the $14^{\text {th }}$ day, and as compared with the group of animals on the $7^{\text {th }}$ day of the study it was higher (by 1.22 times; $\mathrm{P}<0.01)$. However, in comparison with the control group, the level of reduced glutathione in the serum remained sufficiently low (less than 1.48 times; $\mathrm{P}<0.01$ ).

As for the changes in the activity of the enzymatic link of the glutathione system, it turned out that the activity of glutathione peroxidase in animals with inflammation in the periodontal complex was significantly lower on the $7^{\text {th }}, 14^{\text {th }}$ and $30^{\text {th }}$ days of the experiment as compared

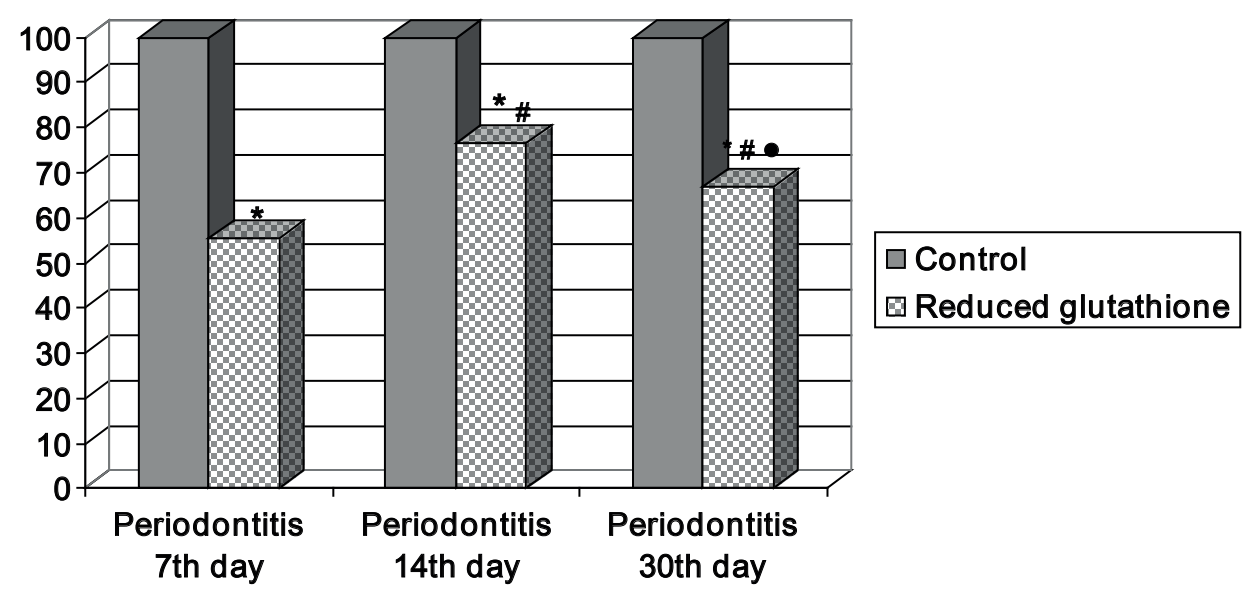

Fig. 3. Reduced glutathione level in rats` blood serum with the experimental periodontitis ( $\%$ of the control). Notes: * - significant of differences in relation to the intact animals $(\mathrm{P}<0.01)$; \# - significant of differences in relation to the animals with periodontitis on the $7^{\text {th }}$ day of the study $(\mathrm{P}<0.01)$; $\bullet$ - significant of differences in relation to the animals with periodontitis on the $14^{\text {th }}$ day of the study $(\mathrm{P}<0.01)$ 
to control indices (Table). Thus, in the animals group that were investigated on the $7^{\text {th }}$ day of the experimental periodontitis, the activity of glutathione peroxidase was lower (by 1.56 times; $\mathrm{P}<0.01$ ) as compared to control group (Fig. 4). In the following day, that is, on the $14^{\text {th }}$ day, was observed significant increase in level (by 1.40 times; $\mathrm{P}<0.01$ ) in comparison with the previous period. However, during this period the activity of this enzyme was lower than in the control (by 1.11 times; $\mathrm{P}<0.01$ ).

Through 30 days the activity of glutathione peroxidase significantly was decreased in comparison with the results that were on the $14^{\text {th }}$ day of the development of the experimental periodontitis (by 1.16 times; $\mathrm{P}<0.01$ ) and as compared with the control (by 1.29 times; $\mathrm{P}<0.01$ ), but remained at the highest level (by 1.21 times; $\mathrm{P}<0.05$ ) as compared with data that was on the $7^{\text {th }}$ day of the study.

The activity of glutathione reductase on the $7^{\text {th }}$ day of the experiment was lower (by 2.83 times, $\mathrm{P}<0.01)$ as compared to the control. It should be noted, that on the $14^{\text {th }}$ day was observed increase index in comparison with the previous study period (by 2.22 times, $\mathrm{P}<0.01$ ), but was lower than the control level (by 1.28 times, $\mathrm{P}<0.01)$. On the $30^{\text {th }}$ day of the periodon- titis development the activity of that enzyme was further decreased in comparison with the data obtained on the $14^{\text {th }}$ days after modeling pathological process (by 1.27 times, $\mathrm{P}<0.01$ ), but it was higher compared with the $7^{\text {th }}$ day - by 1.16 times $(\mathrm{P}<0.01)$, respectively. When compared the level of glutathione reductase activity, in the late period (on the $30^{\text {th }}$ day), with the data of intact animals, they was found statistically significantly lower (by 2.22 times, $\mathrm{P}<0.01$ ).

Thus, the data obtained in the all investigated terms of development and course of experimental periodontitis evidence about take part glutathione system in the mechanisms of this pathology.

\section{CONCLUSION}

1. Inflammatory process in the periodontal tissues, caused by the combined effect of bacterial and immune factors, is accompanied dynamic changes of the enzymic and non-enzymic link of the antioxidant system, an increased activity in the stages of early manifestations (7-14 days) and inhibition in the late period (30 days).

2. The intensity and character of the changes of the antioxidant potential in the blood serum in the experimental periodontitis depends on

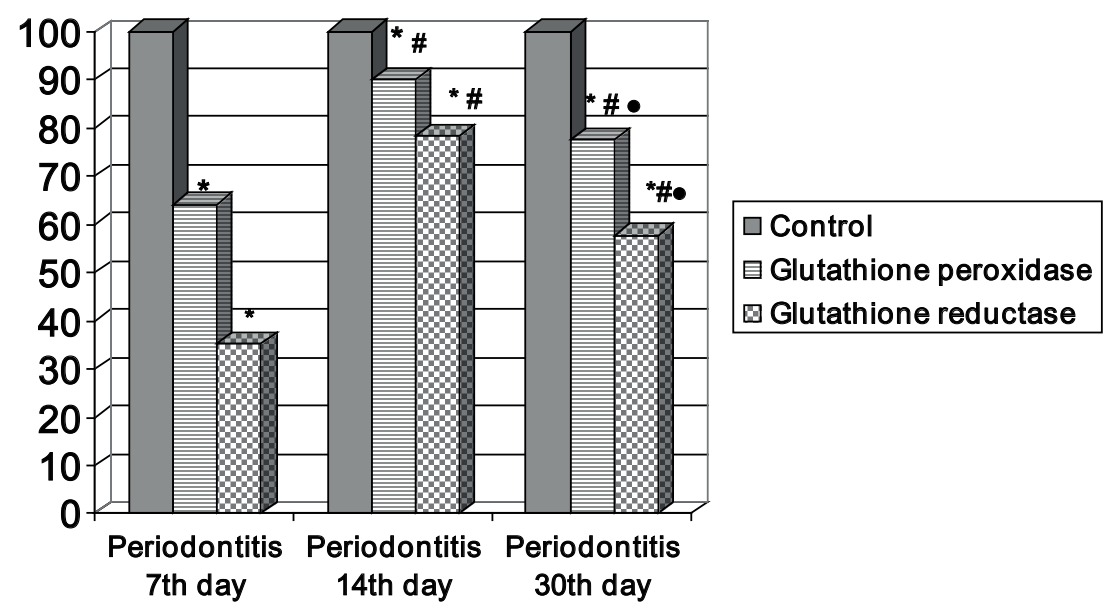

Fig. 4. Glutathione peroxidase and glutathione reductase activity in rats ` blood serum with the experimental periodontitis $(\%$ of the control group). Notes: * - significant of differences in relation to the intact animals $(\mathrm{P}<0.01)$; \# - significant of differences in relation to the animals with periodontitis on the $7^{\text {th }}$ day of the study $(\mathrm{P}<0.01)$; $\bullet$ - significant of differences in relation to the animals with periodontitis on the $14^{\text {th }}$ day of the study $(\mathrm{P}<0.01)$ 
the character of the alterative processes in the inflammatory area, which due to at first formation bacterial, later - immune process, as well as the duration of its course.

3. In the mechanism of development, course and completion of the experimental bacterial and immune periodontitis leading role play the dynamic changes of antioxidant potential, as evidence the corresponding sequence and direction of the changes in different periods, beginning from acute manifestations of inflammation and maintaining its at a high level to exhaustion and chronization of pathologic process.

The authors of this study confirm that the research and publication of the results were not associated with any conflicts regarding commercial or financial relations, relations with organizations and/or individuals who may have been related to the study, and interrelations of coauthors of the article.

\section{А. Є. Демкович, Ю. І. Бондаренко \\ ЗМПНИ АНТИОКСИДАНТНОГО ПОТЕНЦАЛУ ПРИ РОЗВИТКУ ЕКСПЕРИМЕНТАЛЬНОГО ПАРОДОНТИТУ}

У статті наведено результати біохімічних досліджень стану системи антиоксидантного захисту, що визначали за активністю супероксиддисмутази (СОД), каталази, церулоплазміну, глутатіопероксидази, глутатіонредуктази та відновленого глутатіону на 7-му, 14-ту і 30-ту доби розвитку експериментального пародонтиту. Показано, що генерація активних форм кисню, поєднана 3 підвищенням активності імунних процесів, стає більш потужною та надає запальному процесу в тканинах пародонта затяжного характеру. При цьому слід відмітити характерну динаміку показників активності процесів пероксидного окиснення ліпідів та системи антиоксидантного захисту в розвитку експериментального пародонтиту. У ранній період розвитку експериментального пародонтиту, тобто на 7-му добу, активність СОД у сироватці крові знижувалася, а пізніше, на 14-ту та 30-ту добу, підвищувалася. На 7-му добу експерименту підвищувалась активність каталази та церулоплазміну в сироватці крові порівняно з контролем, на 14-ту добу відбулося їх зниження порівняно з групою тварин, досліджених на 7-му добу експерименту, а на 30-ту добу рівень їх у сироватці крові ще зменшився. Активність відновленого глутатіону зменшувалася аналогічно динаміці супероксиддисмутази. Частково активність ферментів системи глутатіону (глутатіонпероксидази, глутатіонредуктази) підвищилася на 14-ту добу запальної реакції, але надалі ці показники набули протилежних змін. Встановлено, що за умов формування і перебігу експериментального пародонтиту змінюється інтенсивність активності антиоксидантного захисту, що важливо для прогнозування його наслідків.

Ключові слова: пародонтит; каталаза; супероксиддисмутаза; церулоплазмін; відновлений глутатіон; глутатіонпероксидази; глутатіонредуктази; антиоксидантний захист.

ДВНЗ «Тернопільський державний медичний університет імені І. Я. Горбачевського МОЗ України»

\section{А. Е. Демкович, Ю. И. Бондаренко}

\section{ИЗМЕНЕНИЯ АНТИОКСИДАНТНОГО ПОТЕНЦИАЛА ПРИ РАЗВИТИИ ЭКСПЕРИ- МЕНТАЛЬНОГО ПАРОДОНТИТА}

В статье приведены результаты биохимических исследований состояния системы антиоксидантной защиты, которую определяли по активности супероксиддисмутазы (СОД), каталазы, церулоплазмина, глутатиопероксидазы, глутатионредуктазы и восстановленного глутатиона на 7, 14 и 30-е сутки развития экспериментального пародонтита. Показано, что генерация активных форм кислорода, сопряжена с повышением активности иммунных процессов, становится более мощной и предоставляет воспалительному процессу в тканях пародонта затяжной характер. При этом обращается внимание на характерную динамику показателей активности процессов перекисного окисления липидов и системы антиоксидантной защиты в развитии экспериментального пародонтита. В ранний период развития экспериментального пародонтита, то есть на 7-е сутки, активность СОД в сыворотке крови снижалась, а позже, к 14-м и 30-м суткам, повышалась. На 7-е сутки эксперимента было выявлено повышение активности каталазы и церулоплазмина в сыворотке крови по сравнению с контролем, на 14-е сутки они снижались по сравнению с группой животных, исследованных на 7-е сутки, а на 30-е сутки уровень их в сыворотке крови еще уменьшился. Изменение содержания восстановленного глутатиона были аналогичными с динамикой супероксиддисмутаза, то есть на 7-е сутки происходило их снижение. Частичное повышение активности ферментов системы глутатиона (глутатионпероксидазы, глутатионредуктазы) наблюдалось на 14-е сутки воспалительной реакции, но в дальнейшем эти показатели приобрели противоположных изменений. Установлено, что в условиях формирования и течения экспериментального пародонтита меняется интенсивность активности антиоксидантной защиты, что важно для прогнозирования его последствий.

Ключевые слова: пародонтит; каталаза; супероксиддисмутаза; церулоплазмин; восстановленный глутатион; глутатионпероксидаза; глутатионредуктаза; антиоксидантная защита. 


\section{REFERENCES}

1. Borisenko A. Periodontal disease. Kyiv: Medicine; 2013. [Ukrainian].

2. Dimitrova A, Kolenko Y. Evaluating the effectiveness of various immunomodulators in complex treatment generalized periodontitis in young adults (18-25 years). J Modern Dentistry. 2013; 2: 38-9. [Russian].

3. Butyugin I, Kornilov N, Abramov O. Comparative analysis of the effectiveness of topical application of antioxidants in the treatment of chronic generalized periodontitis. $\mathrm{J}$ Dentistry. 2013; 92(1): 31-4. [Russian].

4. Kolisnyk M, Kolisnyk G, Vlizlo V. Reactive oxygen species and their role in the metabolism of cells. J Biology. 2009; 11(1): 58-69. [Ukrainian].

5. Melnichuk G, Kostyuk I. The evolution of lipid peroxidation and antioxidant protection in the blood serum of children with permanent teeth granulating periodontitis and chronic heightened course, influenced treatment. J Modern Stomatology. 2012; 3: 25-8. [Ukrainian].

6. Nesterov V, Turchenko N. The structural features of the air-blood barrier in conditions of acute lung hypo- and hyperoxic stress. J Science. 2010; 3: 112-6. [Russian].

7. Ascenso A, Ribeiro HM, Marques HC, Simoes S. Topical delivery of antioxidants. Curr Drug Deliv. 2011; 8(6): 640-60.

8. Guant T, Song J, Wang Y, Guo L, Yuan L, et al. : Expression and characterization of recombinant bifunctional enzymes with glutathione peroxidase and superoxide dismutase activities. Free Radic Biol Med. 2017; 8(110): 188-95.

9. Demkovych AY, Bondarenko YI. Pathogenetic basis periodontitis modeling in rats. Achiev of Clin and Exper Med. 2015; 1(22): 54-7. [Ukrainian].

10. Chevari S, Chaba I, Székei J. The role of superoxide reductase in the oxidative processes of the cell and the method of its determination in biological material. Lab Case. 1985; 11: 678-81.

11. Korolyuk MA, Ivanova LI, Mayorova IH. Method for determination of catalase activity. Laboratory case. 1988; 1: 16-8. [Russian]

12. Kolb VH, Kamyshnikov VS. Handbook of Clinical Chemistry. Minsk: Belarus; 1982. [Russian].

13. Moffat JA, Armstrong PW, Marks GS. Investigations into the role of sulfhydryl groups in the mechanism of ac- tion of the nitrates. Can J Physiol and Pharmacol. 1982; 60(10): 1261-6.

14. Kruglikova GO, Stutman IM. Glutathione peroxidase and glutathione reductase activity of rat liver after the introduction of sodium selenite. Ukr Bioch J. 1976; 48 (2): 227-33. [Ukrainian].

15. Orlov A. Cases Mathematics, Probability and Statistics Basic facts. Moscow: MZ-Press; 2004. [Russian].

16. Berger RL, Casella G. Statistical Inference. 2nd ed. Florida: Duxbury Press; 2001.

17. Demkovych AY, Bondarenko YI, inventor; I. Horbachevsky Ternopil State Medical Univ., assignee. Pathogenetic basis periodontitis modeling in rats. Ukraine patent 82388 u201303000. 2013 Jul 25.

18. DemkovychAY. The peculiarities of microbiocoenosis formation in development of inflammatory periodontal diseases. Infectious diseases. 2015; 1(79): 87-92. [Ukrainian].

19. Medynska KO, Shelyuk OV, Lityuha VV. The study of structural characteristics and determine the extent of damage of oxidation-modified rabbit skeletal muscle actomyosin under the influence of ultrasound. Physics Living. 2010; 18(1): 164-7. [Ukrainian].

20. Regeda MS, Boychuk TM, Bondarenko YI, Regeda MM. Inflammation is a typical pathological process. 2 nd ed. Lviv: Korpan; 2013. [Ukrainian].

21. Hussain T, Tan B, Yin Y, Blachier F, Tossou M, Rahu N. Oxidative Stress and Inflammation: What Polyphenols Can Do for Us? Oxid Med Cell Longev. 2016; 2016 : 7432797.

22. Valko M, Rhodes CJ, Moncol J, Izakovic M, Mazur M. Free radicals, metals and antioxidants in oxidative stressinduced cancer. Chem Biol Interact. 2006; 160(1): 1-40.

23. Volchegorskii IA, Kornilova NV, Butiugin IA. Comparative analysis of "lipid peroxidation-antioxidant protection" system status in saliva of patients with slight and moderate stages of chronic parodontitis. Stomatologiia (Mosk). 2010; 89(6): 24-7. [Russian].

24. Bakhautdin B, Febbraio M, Goksov E, Motte CA, Gullen MF, Childers EP, et al. Protective role of macrophagederived ceruloplasmin in inflammatory bowel disease. Gut. 2013; 62(2): 209-19.

25. Linder MC. Ceruloplasmin and other copper binding components of blood plasma and their functions: an update. Metallomics. 2016; 8(9): 887-905. 